\title{
Aktivitas Antimikroba Tanaman Paku (Stenochlaena palustris dan Pteridium caudatum) Terhadap Bakteri (Ralstonia solanacearum dan Streptococcus sobrinus)
}

\author{
(Antimicrobial Activity of Pteridophyte (Stenochlaena palustris dan Pteridium caudatum) Against \\ Ralstonia solanacearum dan Streptococcus sobrinus)
}

Penulis

Afiliasi

\author{
Saat Egra ${ }^{1}$, Mardhiana ${ }^{1}$, Randy Patriawan ${ }^{1}$, Kartina ${ }^{1}$, Sudirman Sirait ${ }^{1}$, Harlinda Kuspradini ${ }^{2}$ \\ ${ }^{1}$ Fakultas Pertanian, Universitas Borneo Tarakan, Indonesia \\ ${ }^{2}$ Fakultas Kehutanan, Universitas Mulawarman, Indonesia
}

\begin{abstract}
ABSTRAK
Tanaman paku merupakan tanaman yang tumbuh subur dan liar di wilayah tropis, kehadirannya dalam dunia pertanian sebagai gulma, namun di sisi lain juga bermanfaat sebagai tanaman obat (hortikultur). Kehadiran tanaman paku sebagai obat diharapkan menjadi alternative bahan baru dalam pengobatan. Penelitian dilaksanakan di Laboratorium Perlindungan Tanaman, Jurusan Agroteknologi, Fakultas Pertanian, Universitas Borneo Tarakan. Sampel yang digunakan yaitu ekstrak daun S. Palustris dan P. Caudatum dengan konsentrasi $2 \%, 1 \%$ dan $0,5 \%$. kontrol positif pada penelitian ini yaitu chloramphenicol dan kontrol negatif etanol $40 \%$. Variabel yang diamati adalah perhitungan faktor kelembaban, persentase rendemen dan persentase diameter daerah hambatan (DDH). Hasil penelitian menunjukkan rendemen ekstrak $P$. Caudatum 2,5\% sedangkan S. Palustris $1.6 \%$. Selain itu hasil DDH menampilkan bahwa ekstrak etanol daun S. palustris dan $P$. caudatum pada konsentrasi $0.5 \%, 1 \%$ dan $2 \%$ tidak mampu menghambat pertumbuhan $R$. Solanacearum, tetapi mampu menghambat $S$. sobrinus dengan diameter tertinggi yaitu $13.7 \mathrm{~mm}$ pada konsentrasi $2 \%$. Perlu dilakukan penelitian lebih lanjut dengan menggunakan pelarut bertingkat pada proses ekstraksi untuk mengetahui golongan polaritas senyawa yang berpengaruh terhadapa aktifitas penghambatan bakteri.
\end{abstract}

\section{ABSTRACT}

Pteridophyta is plants that flourish wildly in the tropics. The pteridophyte are better known as weeds, otherwise agriculture knows it as a medicinal plants (horticulture). In the future, the expected to be an alternative new ingredient in medicine is pterdophyta. The research was conducted at the Plant Protection Laboratory, Department of Agrotechnology, Faculty of Agriculture, Borneo Tarakan University. The samples used were S. Palustris and P. Caudatum leave extracts with concentrations of $2 \%, 1 \%$ and $0.5 \%$. Positive controls in this study were chloramphenicol and negative control of $40 \%$ ethanol. The variables observed were the calculation of the moisture factor, the percentage of yield and the percentage of minimum inhibitory concentration (MIC). The results showed the yield of $P$. Caudatum extract $2.5 \%$ while S. Palustris $1.6 \%$. In addition, the activity of MIC showed that the ethanol extract of the leaves of S. palustris and $P$. caudatum at concentrations of $0.5 \%, 1 \%$ and $2 \%$ were not available to inhibit the growth of $R$. Solanacearum, but were able to inhibit $S$. sobrinus with the highest diameter of $13.7 \mathrm{~mm}$ at concentration of $2 \%$. Further research using multilevel solvents in the extraction process is needed to find out the polarity of compounds that affect bacterial inhibitory activity.
* Corresponding author Saat Egra

email:

saat.egra.shaumi@gmail.com 


\section{PENDAHULUAN}

Kalimantan merupakan pulau terbesar di Indonesia yang beriklim tropis dengan sumber kekayaan hayati yang sangat melimpah. Keanekaragaman hayati tersebut berpotensi untuk dijadikan sebagai tumbuhan obat, insektisida alami, produksi makanan dan minyak serta produksi barang-barang kerajinan tangan. Salah satu tumbuhan yang tumbuh subur di daerah Tarakan adalah tumbuhan paku, karena tumbuhan paku mudah tumbuh subur di daerah dengan lingkungan yang lembab dan beriklim tropis (Arini dan Kinho 2012). Hal ini memungkinkan tumbuhan paku tumbuh liar sehingga keberadaanya dianggap sebagai gulma bagi pertanian seperti tumbuhan paku $P$. caudatum. Disisi lain, sebagian tanaman paku merupakan tanaman hortikultura yang bermanfaat sebagai sayuran, tanaman hias, kerajinan tangan dan obat tradisional. Padahal fungsi utama tanaman hortikultura yang dikenal adalah sebagai penyediaan pangan, ekonomi, kesehatan, dan sosial budaya (Zulkarnain 2010).

Kalimantan merupakan pulau terbesar di Indonesia yang beriklim tropis dengan sumber kekayaan hayati yang sangat melimpah. Keanekaragaman hayati tersebut berpotensi untuk dijadikan sebagai tumbuhan obat, insektisida alami, produksi makanan dan minyak serta produksi barang-barang kerajinan tangan. Salah satu tumbuhan yang tumbuh subur di daerah Tarakan adalah tumbuhan paku, karena tumbuhan paku mudah tumbuh subur di daerah dengan lingkungan yang lembab dan beriklim tropis (Arini dan Kinho 2012). Hal ini memungkinkan tumbuhan paku tumbuh liar sehingga keberadaanya dianggap sebagai gulma bagi pertanian seperti tumbuhan paku $P$. caudatum. Disisi lain, sebagian tanaman paku merupakan tanaman hortikultura yang bermanfaat sebagai sayuran, tanaman hias, kerajinan tangan dan obat tradisional. Padahal fungsi utama tanaman hortikultura yang dikenal adalah sebagai penyediaan pangan, ekonomi, kesehatan, dan sosial budaya (Zulkarnain 2010).

Tumbuhan paku yang memiliki aktivitas antioksidan dan antibakteri karena adanya senyawa metabolit sekunder yang ada pada tumbuhan tersebut, yaitu alkaloid, flavonoid, saponin dan steroid (Khoiri 2009). Ibrahim et al. (2011) melaporkan bahwa senyawa triterpenoid, flavonoid, steroid dan Shikimic acids terdapat pada tumbuhan paku Adiantum capillus. Sedangkan pada tumbuhan kelakai (Stenochlaena palustris) juga mengandung alkaloid, steroid, dan flavonoid yang dapat dijadikan sebagai antibakteri
(Anggraeni, Erwin 2006). Kemampuan sebagai antibakteri ditunjukkan oleh ekstrak metanol paku sayur (Diplazium esculentum) dengan konsentrasi $100 \%$ membentuk diameter daerah hambat pada pertumbuhan bakteri Staphyloccus aureus sebesar 13,33 $\mathrm{mm}$ dan Escherichea coli sebesar $9.20 \mathrm{~mm}$ secara in vitro (Husna et al. 2015). Selain itu, ekstrak etanol daun (Stenochlaena palustris) memiliki aktivitas antibakteri terhadap Salmonella thypi dan Staphylococcus aureus dengan diameter daerah hambat secara berturut-turut $15.20 \mathrm{~mm}$ dan $18.53 \mathrm{~mm}$ pada konsentrasi 12.5\% (Rostinawati et al. 2015).

Tumbuhan paku Stenochlaena palustris dan Pteridium caudatum diduga memiliki potensi yang sama sebagai antibacterial agent. Bakteri yang digunakan dalam penelitian ini adalah bakteri Ralstonia solanacearum dan Streptococcus sobrinus. $R$. solanacearum merupakan penyebab penyakit layu bakteri yang menginfeksi berbagai jenis tanaman terutama famili Solanaceae, seperti penyakit layu bakteri pada tanaman cabai, tanaman tomat, kentang, dan tembakau. Infeksi bakteri tersebut dapat mengakibatkan kegagalan panen pada tanaman tomat sampai $100 \%$ (Adeputri et al. 2016), cara mengendalikan penyakit tanaman tersebut petani sangat tergantung dengan pestisida kimia. Penggunaan pestisida kimia secara berlebihan akan menyebabkan dampak negatif pada lingkungan, oleh karena itu untuk mengurangi efek negatif dari senyawa pestisida kimia perlu dikembangkan penggunaan pestisida nabati. Senyawa metabolit sekunder yang terdapat pada tumbuhan selain dimanfaatkan sebagai obat tradisional juga dapat dimanfaatkan sebagai bahan aktif pestisida nabati (Saifuddin 2014).

Pestisida nabati merupakan pestisida yang aman terhadap lingkungan dan menghasilkan produk pertanian yang sehat karena senyawa kimia yang ada pada pestisida nabati berasal dari tumbuhan. Sebuah penelitian menunjukkan adanya potensi pestisida nabati pada tumbuhan patikan kebo (Euphorbia hirta L.) pada konsentrasi $100 \%$ yang mampu menghambat pertumbuhan $R$. solanacearum, $E$. coli dan $S$. aureus dengan diameter daerah hambat berturut-turut sebesar $18.26 \mathrm{~mm}, 17.06 \mathrm{~mm}$ dan $21.8 \mathrm{~mm}$ secara in vitro (Anggelika et al. 2014).

Senyawa metabolit sekunder yang terdapat pada tumbuhan paku selain diduga memiliki potensi untuk dijadikan sebagai pestisida nabati juga berkhasiat sebagai obat untuk kesehatan gigi dan mulut manusia.

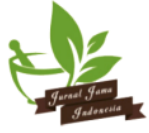


Oleh karena itu, tumbuhan paku S. palustris dan $P$. caudatum diduga memiliki potensi untuk menghambat S. sobrinus yang merupakan salah satu mikroorganisme yang banyak ditemukan di rongga mulut dan merupakan bakteri penyebab awal proses karies gigi. $S$. sobrinus merupakan bakteri penyebab karies gigi karena mampu menghasilkan asam (asidogenik) dan asam laktat, selain itu bakteri ini juga mampu hidup pada lingkungan asam dan anaerobik serta memiliki kemampuan untuk melekat pada permukaan gigi.

Kegunaan dan khasiat yang diperoleh dari berbagai jenis tumbuhan paku sangat banyak terutama di manfaatkan oleh masyarakat sebagai obat tradisional untuk menyembuhkan berbagai macam penyakit, karena tumbuhan ini mudah didapatkan oleh masyarakat dan tidak memiliki efek samping yang membahayakan kesehatan. Namun sejauh ini masih sedikit penelitian yang mengungkapkan aktivitas antibakteri dari ekstrak daun paku S. palustris dan $P$. caudatum, sehingga perlu dilakukan penelitian untuk mengetahui potensi dari ekstrak daun $S$. palustris dan $P$. caudatum yang dapat menghambat pertumbuhan $R$. solanacearum dan S. sobrinus.

\section{METODE}

\section{Alat dan Bahan}

Bahan baku diambil di lahan Hutan Pendidikan Universitas Borneo Tarakan. Bahan lain yang digunakan adalah aquades, etanol, mikroba $S$. sobrinus dan R. solanacearum, nutrient agar (Difco), chloramphenicol, glukosa (Merck). Peralatan yang digunakan dalam penelitian ini yaitu spektrofotometer model Shimadzu UV Vis 1200 (Shimadzu co, Jepang), evaporator (Eyela, Tokyo), shaker, oven, autoclave model All Americans.

\section{Persiapan Sampel}

Sampel tanaman paku (S. palustris dan P. caudatum) dikumpulkan yang terdiri dari seluruh bagian daun. Selanjutnya sampel dipotong-potong agar terbagi menjadi bagian yang lebih kecil $0.5 \mathrm{~cm}$ agar mudah dalam proses pengeringan. Pengeringan sampel dilakukan di oven pada suhu $39^{\circ} \mathrm{C}$ selama $3 \times 24$ jam. Sampel yang telah kering kemudian dihaluskan dengan blender untuk menghasilkan serbuk kasar. Perendaman dilakukan dengan etanol.

\section{Pengujian Aktivitas Antimikroba}

Bahan utama yang digunakan untuk pembuatan media pertumbuhan bakteri adalah nutrient agar
(DIFCO). Media pertumbuhan bakteri dibuat dengan cara mencampur $20 \mathrm{~g}$ nutrient agar, glukosa $10 \mathrm{~g}$, dan aquades $1000 \mathrm{ml}$ dan dididihkan sampai melarut sempurna, dimasukkan ke dalam botol untuk disterilisasi dengan autoclave pada suhu $121^{\circ} \mathrm{C}$ selama 15 menit. Pengujian antimikroba dilakukan dengan menggunakan metode difusi agar sumuran (Kuspradini dkk, 2012). Dalam pengujian ini sebanyak $20 \mathrm{ml}$ media NA dituangkan ke dalam Petridish yang sudah disterilkan selama 15 menit dengan temperatur $121^{\circ} \mathrm{C}$ dalam autoclave. Setelah itu pada keadaan aseptik (dalam laminar flow) biarkan media mengeras, kemudian dilabur dengan suspensi bakteri dengan densitas setera dengan $10^{6}$ cells $/ \mathrm{ml}$ (standar 0.5 McFarland) sebanyak $100 \mu \mathrm{l}$ kemudian diratakan dengan menggunakan kaca perata dan biarkan mengering selama \pm 60 menit. Selanjutnya ekstrak sampel diuji dalam beberapa konsentrasi $(0.5 \%, 1 \%$ dan $2 \%$ untuk mengetahui efektivitas peningkatan konsentrasi pada aktivitas penghambatan terhadap mikroba uji minimum. Kontrol positif yang digunakan adalah Chloramphenicol dengan dosis $10 \mu \mathrm{g}$ dan kontrol negatif yang digunakan adalah aseton. Aktifitas antimikrobial ditandai dengan adanya zona hambat disekitar sumuran yang mengandung ekstrak, dengan angka lebih besar dari $8 \mathrm{~mm}$ dan dilakukan sebanyak 3 kali ulangan (Kuspradini 2012).

\section{HASIL DAN PEMBAHASAN Hasil}

Pada penelitian ini telah dilakukan pengamatan mengenai uji aktivitas antibakteri ekstrak daun tumbuhan paku (Pteridophyta) terhadap $R$. solanacearum dan $S$. sobrinus secara in vitro. Parameter yang diamati yaitu faktor kelembaban (FK), persentase rendemen, dan persentase penghambatan. Perhitungan faktor kelembaban (FK) dilakukan setelah memperoleh nilai berat kering tanur dari sampel yang digunakan. Perhitungan ini bertujuan untuk mengetahui besarnya kandungan air di dalam bahan. Sampel daun segar $S$. palustris dan $P$. caudatum yang masing-masing berat awal $1 \mathrm{~g}$, diperoleh factor kelembaban daun $S$. palustris yaitu 0.37 dan $P$. caudatum yaitu 0.37 .

\section{Persentase Rendemen}

Proses ekstraksi daun S. palustris dan P. caudatum dilakukan menggunakan metode maserasi. Hasil 
perhitungan persentase rendemen dapat dilihat pada Tabel 1.

Tabel 1. Hasil rendemen ekstrak

\begin{tabular}{lccc}
\hline \multicolumn{1}{c}{ Sampel } & $\begin{array}{c}\text { Bobot } \\
\text { awal (g) }\end{array}$ & $\begin{array}{c}\text { Bobot } \\
\text { ekstrak (g) }\end{array}$ & $\begin{array}{c}\text { Rendemen } \\
\text { (\%) }\end{array}$ \\
\hline S. palustris & 32.97 & 0.51 & 1.6 \\
P. caudatum & 56.49 & 1.41 & 2.5 \\
\hline
\end{tabular}

Hasil rendemen menunjukkan bahwa jumlah ekstrak etanol $P$. caudatum lebih besar (2.5\%) dibandingkan dengan daun S. palustris (1.6\%). Hal ini diduga semakin tinggi nilai rendemen yang dihasilkan menandakan jumlah ekstrak yang dihasilkan semakin banyak. Selain itu juga dipengaruhi oleh jenis pelarut yang digunakan, semakin polar pelarut yang digunakan maka akan semakin banyak senyawa yang akan terekstrak.

\section{Persentase Penghambatan}

Pengamatan aktifitas antimikroba dilakukan dengan cara mengukur diameter daerah hambat di sekitar sumuran yang mengandung ekstrak dengan menggunakan mistar. Perhitungan persentase penghambatan ditentukan berdasarkan daya hambat relatif terhadap kontrol positif. Hasil perhitungan persentase penghambatan dapat dilihat pada Tabel 2.

Persentase penghambatan menunjukkan bahwa ekstrak daun $S$. palustris dan $P$. caudatum tidak memiliki daya hambat terhadap $R$. solanacearum. Tetapi kontrol positif pada $R$. solanacearum menghambat 100\% (rata-rata DDH $45 \mathrm{~mm}$ ). Sedangkan pada $S$. sobrinus menunjukkan bahwa ekstrak daun $S$. palustris dan $P$. caudatum memiliki aktivitas antibakteri. Ekstrak daun $S$. palustris mampu menghambat $S$. sobrinus pada konsentrasi $0.5 \%, 1 \%$ dan $2 \%$ dengan nilai persentase hambat secara berturut-turut $18.8 \%, 20.9 \%$ dan $26.5 \%$ dengan kontrol positif 100\% (rata-rata DDH $39.2 \mathrm{~mm}$ ). Sedangkan ekstrak P. caudatum pada konsentrasi $0.5 \%, 1 \%$ dan $2 \%$ dengan nilai persentase hambat secara berturut-turut $22.9 \%, 29.7 \%$ dan $37.7 \%$ dengan kontrol positif $100 \%$ (rata-rata DDH $36.3 \mathrm{~mm}$ ).

\section{Pembahasan}

\section{Perhitungan Faktor Kelembaban}

Faktor kelembaban daun $S$. palustris dan $P$. caudatum menunjukkan nilai yang sama yaitu 0.37. Faktor kelembaban dalam suatu bahan sangat diperlukan dalam suatu ekstrak tanaman karena penetapan aktivitas air memberikan batasan minimal besarnya kandungan air dalam bahan. Menurut Isnawati, Arifin (2006) kadar air yang disyaratkan untuk proses ekstraksi tidak boleh melebihi $10 \%$ karena dapat memicu pertumbuhan mikroorganisme. Menurut Susiani et al. (2017) simplisia yang ditumbuhi kapang dan jamur akan berpengaruh pada zat aktif yang terkandung di dalamnya. Oleh karena itu proses pengeringan dilakukan sampai daun dengan kadar air rendah yang diindikasi mudah diremukkan. Menurut Cahyono (2011) bahan yang mudah meremah atau mudah patah setelah pengeringan memiliki kadar air rendah.

Daun dikeringkan dengan cara diangin-anginkan di udara terbuka pada suhu kamar yang terlindung dari sinar cahaya matahari. Hal ini dilakukan untuk menghindari kerusakan kandungan senyawa yang ada dalam suatu simplisia yang mempunyai aktivitas antioksidan dan antibakteri. Hasil penelitian Luliana et al. (2016) pengeringan simplisia daun (Melastoma malabathricum L.) dengan cara pengeringan angin pada suhu kamar memiliki antioksidan tertinggi yaitu $54.60 \%$ dibandingkan dengan cara pengeringan oven pada suhu $40^{\circ} \mathrm{C}(52.76 \%)$, pengeringan sinar matahari langsung (38.06\%), pengeringan sinar matahari tidak langsung (49.19\%) dan sampel segar (35.79\%). Hal ini dikarenakan senyawa antioksidan dan flavonoid bersifat sensitif terhadap cahaya dan panas.

\section{Persentase Rendemen}

Perhitungan persentase rendemen bertujuan untuk mengetahui berapa jumlah simplisia yang diperlukan untuk ekstraksi agar diperoleh sejumlah ekstrak yang diinginkan. Berdasarkan hasil perhitungan yang memiliki nilai persentase rendemen yang tertinggi terdapat pada ekstrak etanol daun $P$. caudatum yaitu

Tabel 2. Hasil perhitungan persentase penghambatan

\begin{tabular}{|c|c|c|c|c|c|c|c|}
\hline \multirow{3}{*}{$\begin{array}{c}\text { Nama } \\
\text { Tumbuhan }\end{array}$} & \multirow{3}{*}{ Bagian } & \multicolumn{6}{|c|}{ Persentase Penghambatan (\%) } \\
\hline & & \multicolumn{3}{|c|}{ Bakteri $R$. solanacearum } & \multicolumn{3}{|c|}{ Bakteri S. sobrinus } \\
\hline & & $2 \%$ & $1 \%$ & $0,5 \%$ & $2 \%$ & $1 \%$ & $0,5 \%$ \\
\hline S. palustris & Daun & $0 \%$ & $0 \%$ & $0 \%$ & 26.5 & 20.9 & 18.8 \\
\hline P. caudatum & Daun & $0 \%$ & $0 \%$ & $0 \%$ & 37.7 & 29.7 & 22.9 \\
\hline
\end{tabular}


$2,5 \%$ sedangkan daun S. palustris yaitu $1,6 \%$. Hal ini diduga karena bobot simplisia yang digunakan pada daun $P$. caudatum lebih besar (56.49 g) sedangkan daun S. palustris (32.97 g). Menurut Irsyad (2013) hasil rendemen dapat dijadikan acuan untuk mengetahui jumlah simplisia yang dibutuhkan untuk pembuatan sejumlah tertentu ekstrak kental. Selain itu, penentuan rendemen juga berfungsi untuk mengetahui kadar metabolit sekunder yang terekstrak oleh pelarut yang digunakan (Ukieyanna 2012).

Menurut Febrina et al. (2015) metode ekstraksi yang digunakan merupakan salah satu faktor yang akan mempengaruhi rendemen suatu ekstrak. Ekstraksi menggunakan pelarut terdiri dari cara dingin, meliputi maserasi, perkolasi dan cara panas meliputi refluks, soxhletasi, infus, dekoh, dan digesti. Sampel S. palustris dan $P$. caudatum diekstraksi dengan metode maserasi. Maserasi dilakukan dengan merendam simplisia menggunakan pelarut dengan pengadukan pada suhu ruang. Metode maserasi dipilih sebagai proses ekstraksi karena metode ini merupakan metode ekstraksi cara dingin, sehingga dapat mencegah terurainya metabolit yang tidak tahan dengan pemanasan.

Ekstraksi dilakukan dengan menggunakan pelarut tunggal yaitu etanol. Menurut Dia et al. (2015) pelarut etanol memiliki polaritas yang tinggi yaitu 4,3 sehingga dapat mengekstrak senyawa yang bersifat polar, diantaranya senyawa fenolik, steroid, terpenoid, alkaloid dan glikosida. Selain itu, etanol dapat bercampur dengan air pada segala perbandingan, absorbsinya baik, netral, dan tidak beracun (Anggraeni, Erwin 2015).

\section{Persentase Penghambatan}

Metode yang digunakan pada pengujian aktivitas antibakteri ekstrak etanol daun $S$. palustris dan $P$. caudatum adalah metode difusi agar (sumuran), seperti yang telah dilakukan (Kuspradini 2012). Aktivitas penghambatan ekstrak $S$. palustris dan $P$. caudatum dilihat dengan terbentuknya zona hambat (zona bening) disekitar sumuran setelah diinkubasi selama 18-24 jam pada suhu $37^{\circ} \mathrm{C}$. Perhitungan persentase penghambatan yang digunakan sebagai kontrol positif yaitu Chloramphenicol, karena berspektrum luas yang efektif untuk menghambat bakteri Gram positif dan Gram negatif. Menurut Olson (2004) mekanisme dari Chloramphenicol yaitu menghambat sintesis protein, mencegah ujung aminoasil t-RNA bergabung dengan peptidil transferase. Sedangkan kontrol negatif yang digunakan yaitu etanol $40 \%$ untuk mengetahui ada tidaknya pengaruh pelarut terhadap pertumbuhan $R$. solanacearum dan $S$. sobrinus. Sehingga dapat diketahui bahwa yang mempunyai aktivitas antibakteri adalah zat uji bukan pelarut. Hasil uji aktivitas antibakteri ekstrak daun $S$. palustris dan $P$. caudatum terhadap $R$. solanacearum diamati setelah inkubasi 1824 jam dapat dilihat pada Gambar 1.

Gambar 1. menunjukkan bahwa ekstrak S. palustris dan $P$. caudatum tidak dapat menghambat pertumbuhan $R$. solanacearum. Hal ini diduga karena senyawa aktif pada ekstrak daun $S$. palustris dan $P$. caudatum sebagai antibakteri jumlahnya sedikit. Heriyati et al. (2016) melaporkan semakin tinggi senyawa metabolit sekunder maka kemampuan penghambatan meningkat terhadap pertumbuhan
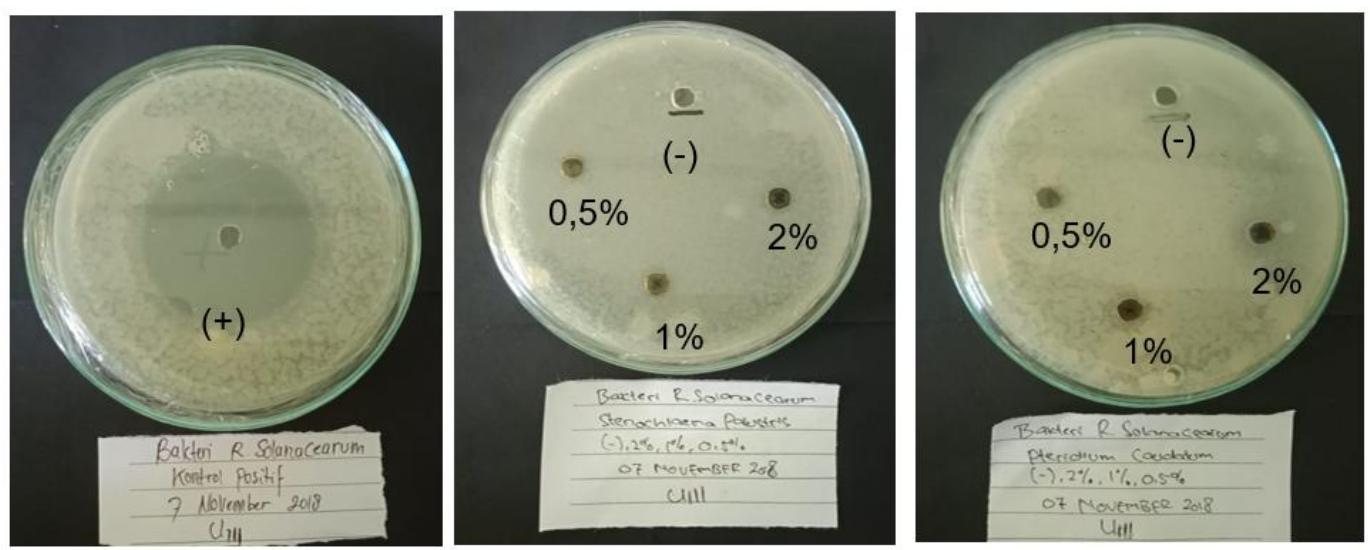

Gambar 1. DDH ekstrak S. palustris dan P. caudatum pada konsentrasi $2 \%, 1 \%$ dan $0.5 \%$ terhadap bakteri $R$. solanacearum

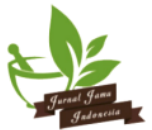


bakteri. Anggelika et al. (2014) menunjukkan ekstrak tumbuhan petikan (Euphorbia hirta L.) dengan konsentrasi $100 \%$ mampu menghambat pertumbuhan bakteri $R$. solanacearum sebesar $18.26 \mathrm{~mm}$. Menurut Firmansyah (2015) senyawa bioaktif dikatakan mempunyai aktivitas yang tinggi terhadap mikroba apabila mempunyai nilai konsentrasi penghambatan mikroba yang terendah, tetapi mempunyai diameter penghambatan yang besar. Berdasarkan hasil uji aktivitas antibakteri ekstrak daun $S$. palustris dan $P$. caudatum terhadap $S$. sobrinus dapat dilihat pada Gambar 2.

Gambar 2 menunjukkan hasil positif dengan terbentuknya zona hambat disekitar sumuran pada $S$. sobrinus yang berisi ekstrak $S$. palustris dan $P$. caudatum. Hal ini disebabkan oleh keberadaan metabolit sekunder sehingga memberikan pengaruh terhadap pertumbuhan bakteri uji. Kandungan metabolit sekunder yang terdapat pada tumbuhan paku secara umum adalah alkaloid, flavonoid, saponin, dan steroid (Khoiri 2009). Menurut Shirotake (2014) mekanisme zat antimikroba bekerja secara ekstraseluler dan intraseluler. Ekstrakseluler dengan cara menghambat sintesis dinding sel, menurunkan permeabilitas membran sel dan menurunkan fungsi asam nukleat. Intraseluler dengan cara menghambat sintesis protein dan sintesis asam folat. Aktivitas antibakteri terdiri dari 2 jenis yaitu aktivitas bakteriostatik yang bersifat menghambat pertumbuhan bakteri dengan menginfeksi komponen yang dibutuhkan untuk berkembang biak, seperti mensintesis protein, mengganggu sintesis DNA dan menurunkan permeabilitas membran sel. Sedangkan aktivitas bakterisidal yaitu menghambat pembentukan dinding sel dan bersifat toksik pada sel bakteri (Pratiwi 2017).

Menurut Nurjanah et al. (2018) uji aktivitas antibakteri dilakukan dengan metode difusi dan metode pengenceran. Metode difusi yaitu mengukur diameter zona bening oleh suatu senyawa dalam ekstrak. Metode difusi dilakukan dengan metode agar sumuran. Sedangkan metode pengenceran yaitu senyawa antibakteri diencerkan dari berbagai macam konsentrasi kemudian masing-masing konsentrasi ditambahkan suspensi bakteri uji dalam dalam media cair. Setelah itu diinkubasi selama 18-24 jam. Oleh karena itu, hasil uji Konsentrasi Hambat Minimum (KHM) menunjukkan bahwa konsentrasi $11 \%$ menghambat pertumbuhan bakteri S. mutans dan pada konsentrasi $16 \%$ menghambat pertumbuhan bakteri $S$. sanguinis. Kemudian konsentrasi yang menghambat bakteri tersebut dikultur ulang pada media cair tanpa penambahan bakteri uji dan senyawa antibakteri. Hal ini dilakukan untuk mengetahui Konsentrasi Bunuh Minimum (KBM). Hasil uji KBM menunjukkan bahwa daun kembang bulan (Tithonia diversifolia) pada bakteri $S$. mutans bersifat bakterisidal pada konsentrasi 11\% karena media cair terlihat jernih setelah inkubasi, sedangkan S. sanguinis bersifat bakteriostatik karena pada konsentrasi $16 \%$ masih terdapat pertumbuhan bakteri pada cawan petridish.

Rikomah et al. (2017) aktivitas bakteriostatik ditunjukkan dengan adanya bintik putih di daerah zona bening yang diduga sebagai koloni bakteri. Oleh karena itu, dalam penelitian ini ekstrak etanol daun tumbuhan $S$. palustris dan $P$. caudatum bersifat bakterisidal karena tidak ada bintik putih di daerah zona bening. Daun tumbuhan S. palustris dan $P$. caudatum memiliki

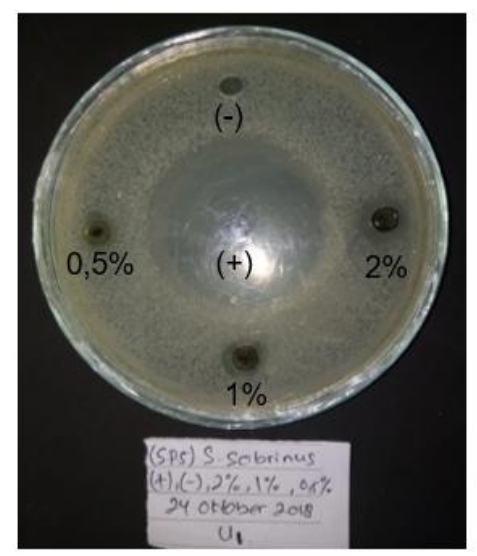

a. S. palustris

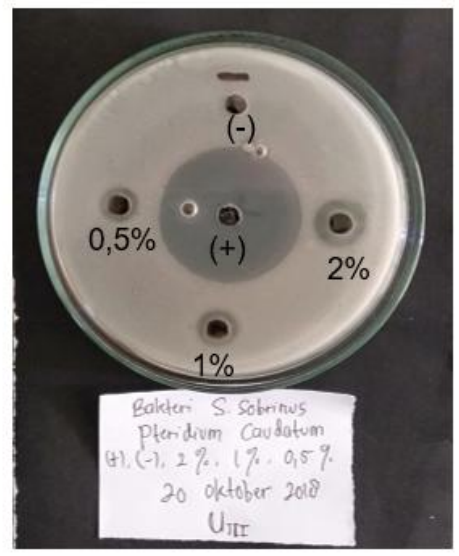

b. P. caudatum

Gambar 2. DDH ekstrak S. palustris dan P. caudatum pada konsentrasi $0.5 \%, 1 \%$ dan $2 \%$ terhadap bakteri $S$. sobrinus. 
aktivitras antibakteri karena adanya senyawa flavonoid yang membentuk senyawa kompleks dengan protein ekstraseluler dan terlarut sehingga dapat merusak membran sel bakteri dan diikuti dengan keluarnya senyawa intraseluler (Heriyati et al. 2016). Saponin yang terkandung dapat menurunkan tegangan permukaan sehingga mengakibatkan naiknya permeabilitas atau kebocoran sel dan mengakibatkan senyawa intraseluler akan keluar (Nuria et al. 2009). Kusumawati (2015) melaporkan saponin bekerja sebagai antimikroba dengan menganggu stabilitas membran sel bakteri sehingga menyebabkan sel bakterilisis. Hal ini menyebabkan sitoplasma bocor sehingga senyawa intraseluler keluar dari sel yang mengakibatkan kematian sel.

Husna et al. (2015) senyawa alkaloid memiliki kemampuan sebagai antibakteri dengan menganggu komponen penyusun peptidoglikan pada bakteri, sehingga lapisan dinding sel tidak terbentuk utuh kemudian menyebabkan kematian sel. Lamothe et al. (2009) melaporkan mekanisme kerja alkaloid yaitu melalui penghambatan sintesis dinding sel yang akan menyebabkan lisis pada sel sehingga sel akan mati. Mekanisme steroid sebagai antibakteri berhubungan dengan membran lipid dan sensitivitas terhadap komponen steroid yang menyebabkan kebocoran (Madduluri et al. 2013).

Berdasarkan dengan nilai persentase penghambatan pada konsentrasi $2 \%$ menunjukkan ekstrak etanol daun S. palustris $(26.5 \%)$ dan P. caudatum $(37.7 \%)$ lebih besar dibandingkan dengan konsentrasi $0.5 \%$ dan $1 \%$. Hal ini menunjukkan semakin tinggi konsentrasi akan semakin besar diameter daerah hambat pada sumuran. Menurut Ajizah (2004) peningkatan konsentrasi suatu ekstrak akan meningkatkan kadar senyawa metabolit sekunder dalam penghambatan pertumbuhan bakteri. Selain itu, besar kecilnya diameter daerah hambat yang terbentuk dapat pula dipengaruhi oleh mutu ekstrak daun. Faktor yang mempengaruhi mutu ekstrak daun yaitu faktor biologi dan faktor kimia. Faktor biologi meliputi spesies tanaman, lokasi tanaman asal, waktu pemanenan, penyimpanan bahan baku, umur serta bagian tanaman yang digunakan. Sedangkan faktor kimia terdiri dari faktor internal seperti senyawa aktif dalam bahan, komposisi kualitatif senyawa aktif, dan kadar total rata-rata senyawa aktif. Faktor eksternal seperti metode ekstraksi, jenis pelarut yang digunakan, kandungan logam berat, ukuran kekerasan dan kekeringan bahan (Maradona 2013).
Berdasarkan hasil analisis diameter daerah hambat $R$. solanacearum menunjukkan pengaruh yang tidak nyata terhadap semua perlakuan rerata diameter daerah hambat. Sedangkan pada $S$. sobrinus menunjukkan pengaruh yang sangat nyata terhadap semua perlakuan rerata diameter daerah hambat. Hal ini diduga karena bakteri Gram negatif dan Gram positif mempunyai dinding sel yang berbeda susunan kimianya. Perbedaan lapisan dinding sel bakteri Gram positif dan Gram negatif.

$R$. solanacearum merupakan bakteri Gram negatif yang memiliki struktur dinding sel yang lebih kompleks sehingga senyawa terkandung pada ekstrak tidak dapat merusak dinding sel pada $R$. solanacearum. Kandou dan Pandiangana (2018) bakteri Gram negatif mempunyai lapisan dinding sel yaitu lipoprotein, lipopolisakarida, dan peptidoglikan. Husna et al. (2015) menyatakan bakteri Gram negatif memiliki sistem seleksi terhadap zat-zat asing yaitu pada lapisan lipopolisakarida dan lapisan selaput luar yang terletak diluar lapisan peptidoglikan pada bakteri Gram negatif berfungsi mencegah kebocoran dari protein periplasma dan melindungi sel.

Wahyuni et al. (2016) porin yang terkandung pada membran terluar bakteri Gram negatif menyebabkan molekul-molekul komponen ekstrak sulit masuk ke dalam sel bakteri. Hal ini disebabkan karena perbedaan sifat antara porin dan ekstrak. Porin bersifat hidrofilik sedangkan ekstrak bersifat hidrofobik. Akibatnya dalam kondisi demikian bakteri dapat bertahan hidup, memperbanyak diri dan mampu menekan produksi metabolit sitotoksik sel fagosit yang menyebabkan terjadinya deaktivasi makrofag melawan infeksi bakteri tersebut. Sedangkan S. sobrinus merupakan bakteri Gram positif yang memiliki struktur dinding sel yang lebih sederhana, sehingga senyawa yang terdapat pada ekstrak lebih mudah merusak dinding sel bakteri. Husna et al. (2015) melaporkan dinding sel bakteri Gram positif hanya tersusun dari satu lapisan yaitu lapisan peptidoglikan yang relatif tebal.

\section{SIMPULAN}

Ekstrak etanol daun $S$. palustris dan daun $P$. caudatum memiliki kemampuan untuk menghambat bakteri S. sobrinus pada kosentrasi $2 \%$ dengan diameter $13.7 \mathrm{~mm}$, namun tidak mampu menghambat pertumbuhan $R$. solanacearum. 
UCAPAN TERIMA KASIH

Penghargaan setinggi-tingginya kepada Laboratorium Kimia Hasil Hutan, Fakultas Kehutanan, Universitas Mulawarman yang telah menyumbangkan bakteri demi menunjangnya penelitian ini. Ucapan terima kasih juga kepada seluruh tim Natural Product Chemistry (Ana, Rofin, Hartini, Ningrum, Wanda)

\section{DAFTAR PUSTAKA}

Adeputri E, Rustikawati, Suryati D, Herison C. 2016. Penapisan tiga puluh tujuh genotif tomat dan seleksi primer RAPD untuk toleransi terhadap layu bakteri (Ralstonia solanacearum). Akta agrosia. 19(1): 28-42.

Ajizah A. 2004. Sensitivitas Salmonella fhypimurium terhadap ekstrak daun Psidium guajava L. Bioscientiae. 1(1): 31-38.

Anggelika, Suprihadi, Pujiyanto. 2014. Uji aktifitas antibakteri ekstrak tumbuhan Euphorbia thirta L. terhadap Ralstonia solanacearum, Escherichia coli, dan Staphylococcus aureus secara in vitro. Biologi. 3(2): 49-58.

Anggraeni D, Erwin. 2006. Uji fitokimia dan uji ekstrak daun kelakai (Stenochlaena palustris). Di dalam: Prosiding Seminar Tugas Akhir Fakultas Matematika dan Ilmu Pengetahuan Alam 2015. Universitas Mulawarman, Samarinda, Juni 2015.

Arini DID, Kinho J. 2012. Keragaman jenis tumbuhan paku (Pteridophyta) di Cagar Alam Gunung Ambang Sulawesi Utara. Balai Penelitian Kehutanan Manado. 2(1): 17-39.

Cahyono B, Huda MDK, Limantara L. 2011. Pengaruh proses pengeringan rimpang temulawak (Curcuma xanhorriza Roxb) terhadap kandungan dan komposisi kurkuminoid. Reaktor. 13(3): 165-171.

Dia SPS, Nurjanah, Jacoeb AM. 2015. Komposisi kimia dan aktivitas antioksidan akar, kulit batang dan daun lindur. Pengolahan Hasil Perikanan Indonesia. 18(2): 205-219.

Febrina L, Rusli R, Mutlihah F. 2015. Optimalisasi ekstrak antioksidan uji metabolit sekunder tumbuhan libo (Ficus variegate Blume). Tropical pharmacy and chemistry. 3(2):74-81.

Firmansyah SB. 2015. Aktivitas Antioksidan dan Antibakteri Ekstrak Metanol Rumput Laut (Surgassum duplicatum J. Agardh) serta Potensinya sebagai Alternatif Pengawet Alami pada Telur Asin. [Skripsi]. Semarang (ID): Universitas Islam Negeri Walisongo,
Heriyati, Khotimah S, Wardoyo ERP. 2016. Aktivitas antibakteri fraksi diklorometan dan N-Heksana paku sisik (Drymoglossum piloselloides L. presl.) terhadap bakteri Staphylococcus aureus dan Salmonella typhi. Protobiont. 5(3): 82-88.

Husna FA, Sulasmi ES, Witjoro A. 2015. Uji Aktifitas Antibakteri Ekstrak Metanol Ental Muda (Diplazium esculentum Retz.) Swartz terhadap Pertumbuhan Staphylococcus aureus dan Escherichia coli secara In Vitro. [Skripsi]. Malang (ID): Universitas Negeri Malang.

Ibrahim ZZ, Ahmed AS, Gouda YG. 2011. Phytochemical and biological studies of Adiantum capillus-veneris L. Saudi pharmaceutical. 19: 65-74.

Irsyad M. 2013. Standarisasi Ekstrak Etanol Tanaman Ketumpangan Air (Peperomia pellucida L. Kunth). [Skripsi]. Jakarta (ID): UIN Syarif Hidayatullah Jakarta.

Jawetz, Ernest, Melnick EAA. 1995. Mikrobiologi untuk Profesi Kesehatan. Bonang, Jakarta.

Kandou FEF, Pandiangana D. 2018. Aktivitas antibakteri ekstrak metanol tumbuhan paku diantara Capillus veneris dan Asplenium nidus terhadap bakteri Gram negatif Escherichia coli. Matematika Dan IImu Pengetahuan Alam Universitas Sam Ratulangi. 7(1): 25-28.

Khoiri M. 2009. Aktivitas Anti Tumor Ekstrak Etanol pada Sel Tumor Kelenjar Mamari Mencit (Mus musculus) $\mathrm{C3H}$. [Tesis]. Bogor (ID): Institut Pertanian Bogor.

Kuspradini H, Susanto D, Ritmaleni, Mitsunaga T. 2012. Phytochemical and comparative study of anti microbial activity of Lepisanthes amoena leaves extract. Biology, Agriculture And Healthcare. 2(11): 80-86.

Kusumawati E, Supriningrum R, Rzadi R. 2015. Uji aktivitas antibakteri ekstrak etanol daun kecombrang (Etlingera elatior Jack) R. M. SM terhadap Salmonella typhi. Manuntung. 1(1): 1-7.

Lamothe RG, Mitchell G, Gattuso M, Diarra MS, Malouin F, Bourab K. 2009. Plant antimicrobialagents and their effects on plant and human pathogens. Molecular sciences. 10: 34003419.

Luliana S, Purwanti Nu, Manihuruk KN. 2016. Pengaruh cara pengeringan simplisia daun senggani (Melastoma malabathricum L.) terhadap aktivitas antioksidan menggunakan metode DPPH (2,2- 
difenil-I-pikrilhidrazi). Pharmaceutical sciences and research. 3(3): 120-129.

Madduluri S, Rao KB, Sitaram B. 2013. In vitro evaluastion of antibacterial activity of five indegenous plants extract agains five bacterial phatogens of human. Pharmacy and pharmaceutical sciences. 5(4): 679-684.

Maradona D. 2013. Uji Aktivitas Antibakteri Ekstrak Etanol Daun Durian (Durio zibehinus L.), Daun Lengkeng (Dimocarpus Longan Lour.) dan Daun Rambutan (Niphelium lappaceum L.) terhadap bakteri Staphylococcus aureus ATCC 25925 dan Escherichia coli ATCC 25922. [Skripsi]. Jakarta (ID): Universitas Islam Negeri Syarif Hidayatullah Jakarta.

Nuria MC, Faizatun A, Sumantri. 2009. Uji aktivitas antibakteri ekstrak etanol daun jarak pagar (Jatropha curcas L.) terhadap bakteri Staphylococcus aureus ATCC 25923, Escherichia coli ATCC 25922 dan Salmonella typhi ATCC 1408. Mediagro. 5(2): 26-37.

Nurjanah S, Isbiyantoro, Fadhillah H. 2018. Ekstrak daun kembang bulan (Tithonia diversifolia) sebagai antibakteri terhadap Streptococcus mutans dan Stretococcus sanguinis. Farmasi lampung. 7(1): 3340.

Olson J. 2004. Belajar Mudah Farmakologi. Jakarta (ID): Buku Kedokteran.

Pratiwi RH. 2017. Mekanisme pertahanan bakteri patogen terhadap antibiotik. Pro-life 4(3): 418429.

Rikomah SE, Yanti YS, Juarsah W. 2017. Uji daya hambat ekstrak etanol daun puding hitam (Graptophylm pictum) pada pertumbuhan bakteri Pseudomonas aeruginosa. Sains dan Teknologi Farmasi. 19(1): 22-26.
Rostinawati T, Suryana S, Fajrin M, Nugrahani. 2015. Aktivitas antibakteri ekstrak etanol daun kelakai (Stenochlaena palustris) terhadap Salmonella typhi dan Staphylococcus aureus dengan metode difusi agar CLSI M02-A11. Farmasi Universitas Halu Oleo. 3(1): 1-5.

Saifuddin. 2014. Senyawa Alam Metabolit Sekunder. Yogyakarta (ID): Deepublish.

Shirotake S. 2014. A new cyanoacrylate colloidal polymer with nove antibacterial mechanism and its application to infection control. Nanomedine Biotherapeautic Discovery. 4(1): 1-7.

Susiani EF, Guntarti A, Kintoko. 2017. Pengaruh suhu pengeringan terhadap kadar flavonoid total ekstrak etanol daun kumis kucing (Orthosiphon aristatus BL. Miq.). Pharmascientech. 1(2): 1-8.

Ukieyanna E. 2012. Aktivitas Antioksidan Kadar Fenolik dan Flavonoid Total Tumbuhan Suruhan (Peperomia pellucida L. Kunth). [Skripsi]. Bogor (ID): Institut Pertanian Bogor.

Wahyuni, Armadany FI, Widasri M. 2016. Uji aktivitas antibakteri secara in vitro ekstrak etanol daun pakis sayur (Diplazium esculentum Swartz) pada mencit jantan galur balb/c yang diinfeksi Salmonella typhi ATCC 14028. Farmasi Fakultas Ilmu Kesehatan Universitas Islam Negeri Alauddin Makassar. 4(2): 43-49.

Widiyanto J, Wulandari A, Lukitasari M. 2017. Identifikasi keragaman paku di kawasan wisata Mojosemi Forest Park. Di dalam: Prosiding Seminar Nasional SIMBIOSIS II. Madiun, 30 September 2017.

Zulkarnain. 2010. Dasar- Dasar Hortikultura. Jakarta(ID):Bumi Aksara.

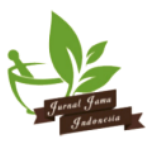

